\title{
Book Reviews Comptes Rendus
}

Peter Hulme and William Sherman, eds. The Tempest and Its Travels. Philadelphia: University of Pennsylvania Press, 2000. Pp. xvi, 319.

For all the centrality of The Tempest to a movement called the New Historicism, the major problem of Shakespeare's play in our time has turned out to be one of geography. In recent accounts of the drama, one question has come to dominate historical scholarship, literary appropriation, and theatrical practice alike: where does The Tempest take place?

The enigma of the play's location began with Shakespeare, who gave his setting no exact spatial or temporal co-ordinates; the Folio editors added to the dramatis personae the phrase, "The Scene, an un-inhabited Island," which is neither precise nor, for that matter, true. The geographical indeterminacy has proved irresistible to interpreters. "No man can therefore conceive anything," wrote Hobbes of the imagination, "but he must conceive it in some place"; and in recent years The Tempest has been conceived in almost every place on earth, and indeed even beyond. Thus in the introduction to their recent Arden edition of the play, Virginia Mason Vaughn and Alden T. Vaughn adduce Renaissance contexts including the New World, Africa, and Ireland; postcolonial adaptations from India, Canada, and throughout the Americas; and film versions set everywhere from Greece to Altair-IV, the Forbidden Planet of science-fiction fame. The Vaughns note several reasons for the "uncommon transportability" of The Tempest, among them its uncertain source, streamlined characters and relationships, elliptical action, and suspended resolution. In these ways Shakespeare has set his island adrift: as it proceeds, the drama makes momentary landfall somewhere in the Mediterranean, North Atlantic, or Caribbean, only to weigh anchor and float off in a wholly new direction. Despite its unusual respect for the unity of place, therefore, The Tempest has become the Shakespearean classic of displacement. In 2001, when London's Almeida Theatre closed its base in Islington to move for a year to a disused coach depot in King's Cross, the valedictory production was 
Jonathan Kent's The Tempest. Outside the theatre the rubble of refurbishment was collecting in piles; inside, Ian McDiarmid's Prospero picked his way through an identical obstacle course of bricks and puddles. Both fiction and reality were construction sites, already on their way to becoming something else, some other place.

The multiple sites and trajectories of Shakespeare's play are the subject of The Tempest and its Travels, co-edited from Essex by Peter Hulme and from Maryland by William Sherman. As befits the many voyages it records, this collection is a cabinet of curiosities. It comprises nearly two dozen commissioned essays, which, as the editors mildly put it, "range in length and directness of approach to The Tempest." What this means in practice is, for instance, that a twenty-page treatise on New World tropes in the play appears alongside a five-page jeu d'esprit on Renaissance hydraulics; or that Davenant and Dryden's The Tempest, or The Enchanted Island gets ten pages of historical analysis, whereas the first part of H.D.'s By Avon River is simply reproduced after two pages of commentary. But differences among the "essays" far from exhaust the book's variety. The three main sections of the volume - on English, Mediterranean, and American contexts, respectively - are interrupted not only by a coyly named "inter-section" on recent stage adaptations, but by "free-standing pages of supplementary material supplied by the editors," which display annotated title pages, poems and early modern artifacts. Add to this a preface, a prologue, three section introductions, a so-called "envoy," and a concluding bibliographical essay, and the ambitious - not to say adventitious - nature of the project becomes clear. The editors' opening observation is that The Tempest has been "located in every place and no place"; in fact, a similar claim might be made of the critical energies marshalled, and yet also curiously dissipated, in their redoubtable anthology.

The bad news is, then, that the contributions are uneven, not only in length but in quality. The perils of commissioning work from almost everyone who has published substantially on The Tempest and its afterlife are here made obvious; too many of the shorter essays have the flavor of postscripts, adding little to the positions established by their authors' monographs. There are, to be sure, exceptions. Roland Greene's piece on "Island Logic" tersely complicates colonial readings by distinguishing the experience of island encounters from "the accumulating and totalizing worldview of the imperial and economic centers"; David Dabydeen offers a blunt but bracing reassessment of Hogarth's A Scene from the Tempest; and Christy Anderson's aforementioned pages on hydraulics, entitled "Wild Waters," are both relevant and refreshing. Apart from these, however, one must look to the longer essays for true innovation. And the good news is that at least four of them have real potential to expand the horizons of current criticism on The Tempest, in ways that should contribute to scholarship and teaching alike.

The most elegant of the essays is Marina Warner's "The foul witch' and Her 'freckled whelp': Circean Mutations in the New World," in which the author of Indigo reads The Tempest in terms of witchcraft and the grotesque. Warner interprets the difference between Sycorax and Prospero less as some contrast of 
black and white magic than as "the difference between metamorphosis and stasis, between a condition of continuing somatic, elemental and unruly mutation and a steady-state identity." Behind Sycorax lies the figure of Circe, whose shapeshifting powers Warner sees extending to the island itself; the play's setting refers at once to the Barbary Coast and the Spanish Main, both of which were historically zones already liminal and hybridized. A useful counterpoint to Warner's essay is "The Mediterranean and Shakespeare's Geopolitical Imagination," where Andrew C. Hess expands his work in The Forgotten Frontier to explore The Tempest as a negative response to contact between Christian and Muslim civilizations. Where Warner sees copious expansion, Hess instead sees defensive inhibition. He claims that any evocations of North Africa in the play serve ultimately to reaffirm the cultural cohesion of early modern Europe: "Shakespeare's avoidance of the Ottoman question, of religious issues, and his defence of Renaissance values simply made both good theatre and smart politics." Here the "steady-state identity" Warner attributes to Prospero acquires a sinister political echo; in it we can hear the integrity of an entire continent being declared.

In due course, however, that integrity came under question from the island margin itself; and a major intervention of this type is chronicled and explicated by co-editor Hulme in his own essay, "Reading from Elsewhere: George Lamming and the Paradox of Exile." Hulme argues that Lamming's chapter in his The Pleasures of Exile (1960) called "A Monster, A Child, A Slave" deserves a central place in Shakespeare studies, and he is persuasive. Lamming has long been celebrated by postcolonial critics, but scholars of the Renaissance could still learn much from his lyrical and incisive reading of The Tempest. (Indeed, several of Lamming's pioneering questions on gender, race, and power have been tacitly adopted by later writers.) Scrupulously read by Hulme, this criticism illuminates both Caribbean culture and the worldwide study of English literature; its value is at once local and global. In this respect it is a worthy follower of The Tempest, especially as the play is refracted through the jewel in Hulme and Sherman's crown, which in my view is Crystal Bartolovich's essay, "'Baseless Fabric': London as a 'World City." To the conundrum, "Where does The Tempest take place?", Bartolovitch proposes a simple answer - London. Or not so simple; for rather than a fixed place of performance that might resolve the imprecise space of the fiction, this early modern London was a city increasingly delocalized by cultural and economic exchange. And like an archipelago, London was in flux, fragmenting and recombining into what Bartolovitch calls "a 'world city' in the modern sense - a necessarily dis-located space, or, to borrow (and transcode) one of Prospero's phrases, a 'baseless fabric.'” To the floating islands of the Mediterranean and the Atlantic evoked in the drama, Bartolovitch decisively adds Britain itself; through such readings as hers, Shakespeare will continue to unsettle easy binaries of the global and the local, and The Tempest will remain, like the protagonist who speaks its epilogue, ever in transit between home and abroad.

ANSTON BOSMAN, Amherst College 